\title{
Teorie principála a agenta a její využití při popisu vztahu volič-zástupce ${ }^{1}$
}

\author{
Principal-Agent Theory and Its Use in Describing the Voter-Representative \\ Relationship
}

JAROSLAVA POSPÍŠILOVÁ ${ }^{2}$

\begin{abstract}
This review article is focused on the rising framework of principal-agent analysis in political science. It aims to map the most influential studies and answer the question of whether this concept is adequate to describe the quality of the relationship between voters and their representatives. It is obvious that using the principal-agent framework leads to oversimplification. The economic theory of democracy is not a new model; nevertheless, using the game theoretic approach requires several adjustments. The adaptation of the main premises of the concept to the political reality should open new research questions with respect to the voter-elected officials relationship. Most principal-agent studies in empirical political science are focused on all links in the delegation chain but the first one. In my opinion, the link between voters and their representatives in a democracy is the fundamental one. Describing it using the tools of principal-agent theory could help scholars better understand current changes in the structure of political parties and voter behaviour.
\end{abstract}

Keywords: Delegation Chain; Voters; Representatives; Principal-Agent Theory; Democracy

\section{1. Úvod}

Moderní podoba demokracie je bytostně spojena s otázkou reprezentace. Ačkoli jsou dnes pojmy demokracie a reprezentace mnohdy použíány jako synonyma (Pitkin 2004: 336), už z důvodu jejich historického původu je tento vztah přinejmenším problematický. $V$ politologické literatuře nalezneme bezpočet studií zabývajících se demokracií, její reprezentativní podobou a aktem vládnutí. Jedním z př́stupů, který je inspirován ekonomickou teorií, je analytický př́istup vycházející

\footnotetext{
1 Tento článek vznikl v rámci projektu Specifického vysokoškolského výzkumu Institutu politologických studií Fakulty sociálních věd UK č. 260 342/2016 Současné brozuby politického rádu. 2 Doktorandka, Institut politologických studií FSV UK, U Křřže 8, 15800 Praha 5-Jinonice / Ph.D. candidate, Institute of Political Studies, Faculty of Social Sciences, Charles University, Prague, Czech Republic. E-mail: jaroslava.pospisilova@fsv.cuni.cz.
} 
z premis ekonomické teorie principála a agenta (např. Lupia a Mccubbins 2000; Kiewiet a McCubbins 1991; McCarty a Meirowitz 2007; Müller 2000; Strøm et al. 2006). Aplikace ekonomických schémat a teorií prí analýze demokratického procesu není ničím novým. Inspirován Schumpeterem vytvořil Downs (1957) svůj ekonomický model demokracie, jehož základním axiomem je vlastní zájem. Politické strany (resp. politici) usilují o své (znovu)zvolení, přičemž tato motivace je základním motorem všech demokratických vztahů a procesů. Ač je ekonomický pohled na demokracii bezpochyby zjednodušující a $\mathrm{v}$ některých ohledech až schematický, jistá míra zjednodušení umožňuje přehledně rozkrýt strukturu vztahů mezi jednotlivými aktéry v rozhodovacím procesu. Centrální postavení vztahu voliče a jeho zástupce při analýze fungování demokratického vládnutí s důrazem na racionalitu umožňuje chápat následné vztahy jako konsekvence celého procesu, nikoli jako nahodilé. Tyto vztahy jsou v samém jádru zastupitelské demokracie, behaviorální prŕstup lze tedy využít i při popisu změn, kterými současná demokracie prochází. Už Downsovo pojetí demokracie pracuje s premisami, které jsou později podrobně rozpracovány $\mathrm{v}$ modelu principála a agenta. Pitkin však Downsův ekonomický model kritizuje pro jeho nedostatečnou reflexi komplexity problematiky reprezentace (1967: 83). Chápeme-li reprezentanty pouze jako agenty politických stran (jak podle ní Downs a Schumpeter činî), vyvstává otázka nedostatečné reprezentace zájmů. Pitkin jde ve své kritice ještě dál a označuje Downsův ekonomický model demokracie jako neslučitelný s reprezentací tak, jak ji chápe ona. Podobně Besley (2006: 31-34) kritizuje předpoklad dostředivosti politické soutěže, na němž je Downsův model vystavěn. Obraz politiky jako boje o středového voliče neskýtá dostatečný prostor pro modelování reality. Před nekritickým přejímáním ekonomických konceptů varuje i Říchová (Říchová a kol. 2015: 57), „nebot’ rozhodování politických aktérů se pohybuje $\mathrm{v}$ jiném okolí a má $\mathrm{i}$ jinou organizační strukturu než běžný podnik“. Je nepochybné, že pro využití ekonomického modelu $\mathrm{v}$ prostředí politiky je nezbytná jeho adaptace.

Teorie principála a agenta (PA) vznikla jako ekonomická teorie analyzující vztahy delegace ve firmách, později našla své uplatnění i v dalších oblastech ekonomie - jako např. v managementu, pojišt'ovnictví atd. (Ross 1973; Eisenhardt 1989; Marek 2007). Vztahy delegace ovšem nejsou vždy pouze ekonomické, problematiku reprezentace analyzuje samozřejmě i politická věda. Jak již bylo zmíněno výše, setkáme se s modelem PA standardně zejména v otázce politické reprezentace (např. Pitkin 1967; Urbinati a Warren 2008; Mansbridge 2003; Rehfeld 2011; Lane 2009). Jak upozorňují Dufek a Holzer (2013: 117) existují v politologické literatuře zabývající se demokratickou reprezentací dva „světy“, přičemž ten empirický končí své studie tam, kde analýzy normativního v podstatě začínají. Dalším úskalím při studiu demokratické reprezentace je pak pojmový aparát, jenž tyto světy bohužel nesdílejí. V empiricky orientované literatuře vycházející z předpokladu, že delegace moci prostřednictvím voleb a s ní 
související koncept odpovědnosti jsou základními myšlenkami konstituujícími moderní demokratickou vládu, je model PA přejímán a chápán mnohem více v duchu jeho ekonomického vyjádření (Strøm 2006; Moe a Caldwell 1994; Katz 2014; Weingast 1997; Besley 2006). V Evropě je ekonomický model PA dominujícím př́stupem $\mathrm{v}$ analýzách delegačního řetězce (chain of delegation), $\mathrm{v}$ USA je naopak využíán zejména ve studiu efektivity byrokracie (public policy), (Braun a Guston 2003; Gilardi a Braun 2002). Na teorii PA rovněž navazují další analytické př́stupy, jako např́ílad prostorové modelování (spatial models).

Následující článek je především přehledovou studií, která si klade za cíl přibližit českému publiku tuto vlivnou a zajímavou teorii, nebot' s jejím využitím se v české politické vědě setkáme spíše okrajově. Vzhledem k multidisciplinaritě př́stupo̊ je nezbytné nejprve vymezit některé pojmy, se kterými budu dále pracovat, následně bude prezentován teoretický koncept modelu principála a agenta pocházející z ekonomie, přehled několika významných př́íladů jeho využití v otázce demokratické reprezentace a následně návrh modelu ve vztahu volič - zástupce v kontextu uspořádání demokratických institucí v Česku, jehož smyslem je zejména otevrít odbornou diskuzi nad jeho možným využitím při zkoumání kvality české demokracie.

\section{2. Úskalí terminologie}

V české politologické literatuře se s využitím modelu PA setkáme velmi zrrídka, a to zejména $\mathrm{v}$ analýzách oboru mezinárodních vztahů, ale i při analýzách agendy zadávání veřejných zakázek a s nimi spojené otázky korupce. Přístup autorů k terminologii není nijak ustálen. Nahlédneme-li do ekonomických statí, setkáme se nejčastěji s počeštěnými termíny „principál a agent“ (Marek 2007; Hlaváček a Hlaváček 2008; Bobek 2014). Někteři autoři aplikující model PA na prostředí politiky ale pracují i stermíny jako „př́kazce-vykonavatel“ (Otáhal 2009), „Zmocnitel-zmocněnec“ (Karlas 2011), „pán-správce“ (Zajícová 2015) nebo „patron-agent“ (Bahenský 2014). Vzhledem k tomu, že hlavním zájmem tohoto článku je vztah delegace moci $\mathrm{v}$ demokracii, nabízí se skutečně překlad „zmocnitel-zmocněnec“. Tento překlad ostatně využívá ve své knize i Dvořák (2017: 21), jež je zatím zřejmě nejucelenějším představením teorie PA a následnou aplikací jejích premis a terminologie $\mathrm{v}$ české politologické literatuře. Z důvodu jasné návaznosti na bohatou zahraniční literaturu se mi přesto jeví jako nejvhodnější zachování původní terminologie, která sice není zpočátku tak zřejmá, následně ale lépe koresponduje s dostupnými zdroji. Při popisu konkrétních prŕkladů z demokratické praxe pak používám termíny volič - (volený) zástupce.

Problematika politické reprezentace je samostatným odvětvím demokratické teorie a její rozbor sahá daleko za hranice tohoto článku. Ačkoli bývají mnohdy termíny reprezentace a zastoupení používány jako synonyma, v demokratické teorii jsou oba termíny odlišovány a pro mnou zkoumaný vztah se ustálil termín 
reprezentace (Gelnarová 2010; Brim a Dufek 2012). Reprezentace chápaná jako vztah principála a agenta je jedním ze čtyř hlavních znaků moderní reprezentativní demokracie (Urbinati a Warren 2008: 389). ${ }^{3}$ Samotný koncept politické reprezentace je mnohem širši a nelze ho redukovat na vztah vzniklý volebním aktem, jemuž se v této stati věnuji.

Větší úskalí ve sladění terminologie skýtá otázka delegace. Empirická teorie analyzující vztahy předání moci a vztahy odpovědnosti pracuje standardně s termínem chain of delegation (Strøm 2000), nabízí se tedy český překlad řetězec delegace. V normativní demokratické teorii ovšem delegace odkazuje na dichotomii „delegate-trustee“ (př́p. mandate-independence podle Pitkin [1967]) (Mansbridge 2011: 621). Zatímco „delegate“ jedná pouze v zastoupení svého principála a je vázán jeho zájmem, „trustee“ je ve výkonu své funkce mnohem více nezávislý. Otázka zájmu je i v ekonomických modelech PA stěžejní a její řešení při aplikaci PA na vztah volič-zástupce není jednoznačné. Mansbridge navrhuje tento tradiční burkeánský koncept „trustee“ $\mathrm{v}$ současné teorii opustit a nahradit modelem selekce, který lze „aplikovat na všechny formy vztahů principála a agenta“ (Mansbridge 2011: 622). Základní otázkou ve vztahu principála a agenta pak není suverenita principála, nýbrž jeho postoj k sankcím. Termín delegace tedy může některým autorům evokovat spíše tuto dichotomii politické reprezentace. Powell místo termínu chain of delegation používá označení chain of responsiveness (Powell 2004). Strøm i Powell chápou delegaci a odpovědnost jako dvě strany jedné mince, $v$ řetězci delegace běží opačným směrem řetězec odpovědnosti. Vzhledem $\mathrm{k}$ tomu, že centrem článku je právě Strømův model, preferuji zachování překladu řetězec delegace, i přes jeho možnou dvojznačnost.

\section{Teorie principála a agenta}

Jak již bylo řečeno výše, má teorie principála a agenta (PA) svůj původ v ekonomii. ${ }^{4}$ Model PA pracuje se dvěma typy aktérů - principálem, tj. aktérem, který disponuje mocí, a agentem, tj. aktérem, na nějž je moc delegována. Situace, ve kterých je možné využít analýzu pomocí modelu teorie principála a agenta, se vyznačují strukturovanými vztahy principála a agenta, u nichž můžeme pozorovat vzájemnou spolupráci, ${ }^{5}$ ovšem s rozličnými cúli a postoji k riziku.

\footnotetext{
${ }^{3}$ Dalšími znaky jsou pak: 2) v aktu voleb je státní moc určena suverenitou lidu, 3) volební akt je měřítkem odpovědnosti zástupců voličům, 4) s všeobecným volebním právem se (volebnî) reprezentace stala důležitou součástí politické rovnosti.

${ }^{4}$ Normativní demokratická teorie rovněž pracuje s jejím pojmovým aparátem, nicméně přenesení ekonomického př́stupu umožňuje schematicky popsat výhody a nevýhody př́istupu pro prostředí politiky.

5 Otázka spolupráce principála a agenta a otázka zájmu, který agent ve vztahu sleduje, stojí v centru kritiky aplikace ekonomického prrístupu na reprezentaci v politice (Pitkin 1967: 221).
} 
Miller (2005: 205-206) definuje šest nezbytných předpokladů pro využití modelu PA:

Vliv agenta - agent má schopnost ovlivnit výstup

Informačni asymetrie - principál má možnost sledovat výstup agentovy činnosti, kontrola jednotlivých kroků agenta je teoreticky možná, byla by však velmi nákladná, a proto je zapovězena, vyvstává otázka, zda mohou odměny nahradit monitoring?

Asymetrie priorit - předpokládá se, že agent upřednostňuje něco jiného než principál (např. principál se snaží snížit náklady na spokojenost agenta, což může vést $\mathrm{k}$ agentovu „zaháleni“")

Iniciativa le žicí na straně jednotnébo principála - předpokladem je, že principál jedná racionálně a na základě konzistentního souboru hodnot, je připraven nabídnout agentovi smlouvu

Zpètná indukece založená na sdílené znalosti - principál i agent sdílejí znalost pravidel hry, nákladů, pravděpodobnosti rozdělení výstupů a dalších parametrů, agent ve svém rozhodování bude vždy mírně preferovat vlastní zájem, ten je jeho funkcí v rozhodovacím procesu, s touto znalostí dokáže principál na základě známých parametrů odlišit agentovu možnou nejlepší odpověd’ a její nejlepší výsledek

Vyjednávací ultimátum - principál může vyžadovat od agenta nejlepší možné řešení, principál disponuje možností dát agentovi nabídku „ber nebo neber“

Základní otázkou ve vztahu principála a agenta je problematika kontroly výstupů (Miller a Whitford 2002). Možnosti principála př́mo ovlivňovat rozhodování agenta jsou omezené, agentovy kroky posuzuje na základě výstupů a míry naplnění principálových představ o nejlepším možném řešení. Hlavní charakteristikou vztahu principála a agenta je tedy nerovný př́stup k informacím (Besley 2006: 98-99). Cílem principála je získat co nejlepší výsledek s co nejmenšími vynaloženými náklady. Přímá kontrola agenta je nemožná, př́íp. vysoce nákladná. Kvalitě vztahu mezi principálem a agentem proto významně nahrává jednotnost preferencí, naopak výrazně odlišné preference obou aktérů vztah narušují.

Ekonomická teorie PA pracuje i s dalšími pojmy, které nelze při výkladu opomenout (Strøm 2000). Jedním ze základních problémů, který v delegačním řetězci nastává je żtráta appisobená delegací (agency loss). Je nepochybné, že procesem delegace dochází vždy k určité ztrátě (at' už materiální nebo formální), otázkou je pak její velikost. Aby byl proces delegace smysluplný, musí být ztráta kompenzována výsledkem, jenž ji svou hodnotou převyšuje. Delegací rozhodovacích kompetencí sice principál část svého vlivu ztrácí, přesto výběrem správného agenta může být prospěch plynoucí z výsledku delegace pro principála vyšší než v případě, že by rozhodoval sám. Inherentní součástí delegačního vztahu je otázka informačni asymetrie. Ta se ve vztahu principála a agenta projevuje bud' 
$\mathrm{v}$ př́padě skryté informace (bidden information), tj. nedostatku relevantních informací o agentovi a jeho zájmech, kterými principál prú jeho výběru disponuje. Jde o otázku výběru vhodného agenta, resp. otázku neprǐznivého výbéru (adverse selection). Principál při výběru agenta vždy podstupuje riziko, že vybere špatně. Druhou možností informační asymetrie je existence skryté akce (bidden action). Principál nedisponuje informacemi o akcích agenta, ani nemá dostatek znalostí pro jejich zpětnou indukci. Jedná se o problém morálníbo bazardu (moral haz̧ard). Agent se v prostředí přenesené odpovědnosti chová jinak, než kdyby byl na výsledku zainteresován př́mo. Klasickým př́kladem, kterým bývá otázka morálního hazardu v literatuře vysvětlována, je príklad z pojišt'ovnictví (Eisenhardt 1989). Předpokládá se, že řidič, který si sjedná havarijní pojištění, jedná následně riskantněji, než kdyby toto pojištění neměl, což je v rozporu se zájmy pojišstovny. V delegačním vztahu vždy hrozí riziko, že bude agent po získání pravomocí jednat v rozporu se zájmy svého principála.

\section{Adaptace teorie PA na otázku reprezentace v demokracii}

Vztahy delegace popisované ekonomickou teorií principála a agenta mají $\mathrm{v}$ mnohých aspektech velmi blízko $\mathrm{k}$ vztahům v politice. Rozhodování a delegace pravomocí $\mathrm{v}$ politice se odehrává $\mathrm{v}$ mnohem širším sociálním kontextu než rozhodování ve firmách. Analyzujeme-li procesy v politice prizmatem ekonomické teorie, je třeba mít tyto odlišnosti neustále na paměti. Procesy a jevy zkoumané politology se $\mathrm{v}$ mnohých aspektech liší od ekonomických vztahů, podle nichž byla teorie zastoupení vytvořena. Podle Pitkin (1967: 221) dokonce nemůže jakýkoli pokus o modelové vyjádření fenoménu reprezentace přinést uspokojivé výsledky. Má-li aplikace teorie PA přinést smysluplné výsledky, vyžaduje nezbytně adaptaci na podmínky politiky - především zohlednění specifického kontextu.

Demokracie může být definována různými zpo̊soby. Jednou z možností, ${ }^{6}$ jak rozdělit moderní teoretické př́stupy, je dichotomie pluralistická demokracie (Dahl) vs. elitistická demokracie (Schumpeter). Žrejmě nejhojněji využívanou definicí demokracie je Dahlova definice, ${ }^{7}$ vymezující demokracii především participací občanů na procesu vládnutí - vedle existence svobodných a férových voleb mají občané právo být sami zvoleni, svobodně kritizovat vládu a výběrem

\footnotetext{
${ }^{6}$ Nejedná se pochopitelně o jediné dvě teorie demokracie, nicméně Schumpeter byl se svým elitistickým prŕstupem zdrojem inspirace pro Downsův ekonomický model, má tedy k pojetí demokracie jako vztahu principála a agenta velmi blízko.

${ }^{7}$ Schumpeter naopak redukuje demokracii na výběr zástupců, obyčejní lidé jsou v jeho chápání nekompetentní v otázce vládnutí a mají pouze právo vybírat elity, které se jim ve volbách nabízejí. Downs doplňuje model o smithovský pohled - pokud stávající nabídka elit nevyhovuje poptávce (tj. chybí reprezentace jistých zájmů), vzniká prostor pro vznik nové strany (Downs 1957). Občané nejsou v jeho modelu nekompetentní, naopak jednají při výběru racionálně (a to i v př́ípadě, že se rozhodnou voleb neúčastnit.)
} 
politických představitelů ve volbách ovlivňovat hlavní politická témata (Dahl 2001: 81). Chápeme-li demokracii jako suverenitu lidu, znamená to, že (všichni) občané jsou konečným principálem (ultimate principal) (Strøm 2000: 267), a to jak $\mathrm{v}$ pluralistickém, tak v elitistickém pojetí. Nicméně $\mathrm{v}$ obou př́padech se jedná o agregativní prrístup $\mathrm{k}$ reprezentaci zájmů, rozdíl je pouze v postavení a kontrole agentů. Výrazné oslabení, či dokonce úplnou eliminaci vztahů principála a agenta představují naopak deliberativní prrístupy $\mathrm{v}$ demokracii, či techniky prrímé demokracie.

K delegaci dochází v situaci, kde již není možné (at' už z hlediska kapacity, či kompetence) rozhodovat př́ímo (Strøm 2006). Jak píše Schumpeter (2004: 265): „za hranicemi „přímé demokracie“ leží nekonečné bohatství možných forem, $\mathrm{v}$ nichž se lidé mohou účastnit na vládě nebo ovlivňovat či kontrolovat ty, kdo ve skutečnosti vládnou“. To, co je všem těmto formám vlády společné, je právě akt delegace. Neexistuje jednotné, univerzálně aplikovatelné schéma pro analýzu reprezentace. Každý proces delegace moci odráží rozdílné charakteristiky daných aktérů, tj. konkrétního principála a agenta, a přináší s sebou různá úskalí a ztráty způsobené delegací. Na druhou stranu již samotný model masové demokracie v sobě nutně obsahuje potřebu delegace moci, pokud si má zachovat jistou míru efektivity. Zjednodušeně řečeno je delegace to, co umožňuje „vládám vládnout“ (Kiewiet a McCubbins 1991: 24).

Vztahy reprezentace můžeme naleznout i v jiných než demokratických režimech (Rehfeld 2009), bez možnosti poskytnutí zpětné vazby v podobě odpovědnosti jde však jen o zdánlivé zastoupení. Odpovědnost (accountability) a delegace jsou dva souvztažné koncepty, delegace bez odpovědnosti je pouze hrou na demokracii, Lupia a McCubbins nazývají reprezentaci bez odpovědnosti abdikací (2000). Nemáme-li možnost svého reprezentanta jakkoli v jeho rozhodování korigovat, př́p. mu alespoň dát najevo svůj nesouhlas s jeho jednáním, stává se reprezentace pouze fikcí. Konstituce vztahu odpovědnosti mezi voličem a politikem je smyslem demokratické politiky, proto stojí odpovědnost v centru politických modelů PA (Besley 2006: 36). Otázka pochopitelně vyvstává $\mathrm{v}$ prrípadě vymahatelnosti této odpovědnosti. Možnost uplatnit proti „neposlušnému“ agentovi sankce je jedním ze základních konstitutivních mechanismů odpovědnosti (Bovens 2010; Strøm 2006; Manin et al. 1999).

Teoretici politické reprezentace se $\mathrm{k}$ možnosti využití modelu PA staví spíše odmítavě (nap̌r. Pitkin 1967; Urbinati a Warren 2008). Otázka politické reprezentace je podle nich mnohem širší a komplexnější problematikou, kterou nelze redukovat pouze na vztah voliče a jeho voleného zástupce. Empirické přístupy naopak určitou míru zjednodušení plynoucí z modelu PA považují za únosnou a využívají modelu při popisu vztahů v delegačním řetězci. Besley (2006: 105) argumentuje, že aplikace modelu PA na politiku nejlépe odpovídá situacím, kdy je zástupce volen prrímo. Nedochází pak k tříštění odpovědnosti a jejímu 
porušení ve vztahu volič-zástupce. Politické modely PA nejčastěji pracují s nejvíce zjednodušujícím předpokladem homogenního (jednotného) voličstva (Besley 2006: 103). Chceme-li však vytvořit model demokratického zastoupení, který bude co nejlépe odpovídat reálné politice, musíme tento předpoklad zpochybnit (Ferejohn 1999). Kiewiet a McCubbins (1991) rozlišují funkci kolektivního principála (prŕp. kolektivního agenta) a mnohonásobného principála (multiple principals). Role kolektivních aktérů je ztížena potřebou vzájemné koordinace před konkrétní akcí.

\section{a. Problém mnohonásobného principála}

Dilema agenta zastupujícího více principálů naopak spočívá zejména $\mathrm{v}$ nejednotnosti jejich preferencí - tj. agent může jednat v zájmu jednoho ze svých principálů, přičemž jinému tímto krokem ale způsobí ztrátu. Strøm (2006: 65) používá modelového středového voliče, ovšem ani dostředivost politiky (snaha vyhovět co nejširšímu plénu voličů) není zárukou znovuzvolení (Downs 1957: 73). Preference středového voliče při tvorbě politik navíc narušuje deklarovanou rovnost občanů (resp. voličů) a může v konečném důsledku posilovat extremistické tendence.

Nejednotnost hodnot a postojů mnohonásobného principála vnáší do vztahů delegace další problematický aspekt a tím je nejistota. Při rozhodování v prostředí nejistoty roste riziko ztrát (Downs 1957: 202). Čím vyšší je nejistota, tím menší je ochota politiků dělat závažná rozhodnutí (která mohou být potenciálně kontroverzní a vést ke ztrátě obliby u voličů). Vláda se stává méně efektivní a ztráty delegačního procesu rostou. Podobně může nejistota negativně ovlivnit ochotu zvolených zástupců jednat v souladu s danými pravidly. Rozdílné výsledky má řetězec delegace i v př́padě, že je analyzován samostatně, bez kontextu dalšího volebního období. Má-li zvolený zástupce pocit, že bude za svou práci odměněn (resp. znovuzvolen), je motivován jednat v souladu s očekáváními jeho voličů (Besley 2006; Besley a Larcinese 2011; Geys a Mause 2016). Besley (2006) svůj model PA proto koncipuje jako model dvoukolový, který předpovídá existenci efektu konce mandátu (term limit effect) na chování jednotlivých politiků. ${ }^{8}$ Podobně i na straně voliču jako principálů není možné nahlížet na volební akt pouze jako

\footnotetext{
8 Tyto poznatky jsou v souladu s předpoklady teorie her, konkrétně rozdílu mezi hrou konečnou a opakovanou. Conconi et al. (Conconi et al. 2014) ve své studii zpochybňují často proklamovanou teorii vztahu demokracie a míru. Sledováním 177 zemí v časovém horizontu téměř dvou století došli k závěru, že teorie demokratického míru (democratic peace) platí pouze v př́padě, jedná-li se o neomezené volební období. Jinými slovy, má-li politik v demokratické zemi vidinu pokračování svého politického působení v dalším volebním období je nepravděpodobné, že by dobrovolně zahájil nějaký vojenský konflikt. $V$ případě, že se však jedná o poslední volební období, tj. politik již ví, že nemůže být znovu zvolen, blíží se pravděpodobnost zahájení válečného konfliktu hodnotám autokratických vůdců.
} 
na jednotlivou událost. Demokracie je dynamický proces a otázka reprezentace a odpovědnosti se do voličského chování promítá v dlouhodobějším horizontu skrze retrospektivní volbu a prospektivní očekávání (Dalton et al. 2011: 186; Fearon 1999).

\section{b. Problém kolektivního aktéra}

V prostředí politiky se vedle mnohonásobného principála setkáme i s otázkou kolektivního principála, př́p. kolektivního agenta. Zatímco mnohonásobný principál nejedná jednotně a $\mathrm{v}$ tom je jeho hlavní úskalí, kolektivní rozhodování přináší otázku koordinace a sociální nestability. Je-li subjektem PA vztahu kolektivní agent, zaujímá $\mathrm{v}$ této skupině jejich nadřízený prominentní postavení, jež mu umožňuje ovlivňovat výstupy rozhodování (např. lídr politické strany). Postavení lídra může být naopak oslabeno rostoucí volatilitou voličů v prostředí personalizovaných voleb. Zvolený zástupce politické strany má vedle svého lídra tendenci zavděčit se i voličům (Strøm 2000: 284). Inherentní součástí vztahů PA je prostředí oportunismu, které je utvářeno zejména podmínkami skryté akce, nedokonalých informací a specifickou formou strategické vulnerability principála, kterou Kiewiet a McCubbins nazývají Madisonovo dilema (1991: 25).

\section{c. Madisonovo dilema (principálův morální hazard)}

Podstatou Madisonova dilematu je situace, kdy „zdroje nebo pravomoce garantované agentovi za účelem zastupování zájmů principála se mohou proti principálovi obrátit.“(Kiewiet a McCubbins 1991: 26) Madison řeší situaci, kdy vláda stojí př̀ed nelehkým úkolem, nastavit pravidla kontroly těch, kterým vládne a poté nastavit pravidla kontroly sebe sama. Řešením Madisonova dilematu je v zastupitelské demokracii dělba moci. Analyzujeme-li demokracii z pohledu modelu PA, kdy jako zdroj moci (principála) bereme občany, vyvstává další problém, který ekonomická teorie PA neřeší. Agenti totiž svou delegovanou moc používají nejen k prosazování zájmů svých principálů, nýbrž i k jejich kontrole.

V klasické teorii PA je otázka morálního hazardu spojena pouze s osobou agenta, jedině agent je odpovědný principálovi. Vzhledem k faktu, že odpovědnost je jednosměrná, principálův morální hazard vekonomické PA nedává smysl. Procesy zkoumané politickou vědou však podobné situace přinášejí. Př́kladem může být řešení dilemat v legislativním procesu (Miller 2005: 222). Jednotliví legislativci chtějí volit tak, aby maximalizovali své šance na znovuzvolení. To může v krajním př́ípadě vyústit $\mathrm{v}$ nežádoucí chaos, stranický aparát je tedy nucen zvolit jednoho agenta (stranického lídra), jehož úkolem je koordinovat př́p. usměrnit stranickou základnu. Stranická základna je mnohonásobným principálem, jehož primárním zájmem je zachovat si jednotné postoje k vybraným politickým tématům, které od ní její voliči očekávají. Problém, který je třeba řešit, tedy není morální dilema agenta, ale morální hazard 
mnohonásobného principála, nebot' postoje jednotlivých členů mohou být $\mathrm{v}$ rozporu s názorovou linií základny. $\mathrm{V}$ procesech zkoumaných $\mathrm{v}$ politologii nalezneme mnohé situace, které jsou z pohledu ekonomické teorie PA nesmyslné. Agent je často kolektivním principálem volen, aby ovlivňoval jednání samotného principála.

Klasická teorie PA navíc pracuje s předpokladem racionality aktérů. Aktér rozhodující se pouze na základě racionálního uvažování sleduje přirozeně i ve vztazích přednostně svůj zájem a jedná tak, aby maximalizoval svoje zisky a minimalizoval své úsilí (Ř́chová 2000: 105). Vztahy mezi aktéry se však odehrávají v sociálním kontextu, který by mohl mít na rozhodování jedince vliv. Ačkoli formálně bychom na vztahy reprezentace mohli na individuální úrovni aplikovat zjednodušené PA schéma, právě rozšíření konceptu na agregovanou úroveň naráží na nedostatečnou reflexi kontextu. Vztahy PA jsou v sociálním kontextu realizovány na bázi důvěry existující díky společně sdílené skupinové historii a zkušenosti (Urbinati a Warren 2008: 394; Besley 2006: 17) Důvěra je tedy chápána jako formující předpoklad vztahů mezi jednotlivými aktéry. To, zda se vztahy PA odehrávají častěji podle scénáře předpokládaného teorií racionality, či zda odrážejí i sociální realitu, testovali ve svých experimentech Bottom et al. (2006). V klasickém modelu PA nemá vyjednávání své místo, komunikace mezi aktéry nemá žádnou váhu a rozhodování probíhá jako maximalizační funkce. Výsledkem zmíněných experimentů bylo potvrzení role odměn vycházejících $\mathrm{z}$ předpokladů teorie $\mathrm{PA}$, na druhou stranu $\mathrm{v}$ prípadě sdílení rizika tyto odměny fungovali méně efektivně než nástroje založené na vztazích důvěry a reciprocity.

Millerovy předpoklady pro použití modelu PA vztah volič-zástupce s jistými obměnami skutečně splňuje. Vztah voliče a jeho voleného zástupce je vztahem principála a agenta. Volič disponuje mocí, ale sám nemůže moc vykonávat, proto ji deleguje. Má-li se jednat o skutečně demokratickou delegaci, je nezbytnou součástí tohoto vztahu odpovědnost a její vymahatelnost. Volič může svého zástupce potrestat za špatně odvedenou práci přinejmenším v následujících volbách. Kromě nástrojů voličské odpovědnosti vstupuje do vztahu voličzástupce i řada institucionálních omezení, které slouží jako prostředky $\mathrm{k}$ minimalizaci (delegačních) ztrát.

\section{Ztráty způsobené delegací a možnosti jejich minimalizace}

Jak již bylo řečeno výše, každý proces delegace v sobě obsahuje riziko delegačních ztrát. V prostředí zastupitelské demokracie je delegace moci nutným předpokladem efektivního vládnutí, nicméně je nezbytné vždy zahrnout do úvahy riziko s delegací spojených ztrát. Tyto ztráty mohou být $\mathrm{v}$ různé míre, $\mathrm{v}$ zájmu principála je vždy jejich minimalizace. 
V literatuře nalezneme obvykle čtyři strategie vedoucí $\mathrm{k}$ minimalizaci ztrát delegačního procesu (Kiewiet a McCubbins 1991; Strøm 2000; Alvarez a Hall 2006):

\section{Zasmluvnění}

Mechanismy k prověření a výběru kandidáta

Monitoring a požadavek na self-reporting

Institucionální omezení a kontrola

Základním rozdělením těchto mechanismů je oddělení mechanismů ex ante (předcházejí delegaci) a ex post (nástroje odpovědnosti) (Strøm 2006; 2000). První dva body (zasmluvnění a mechanismy $k$ prověření a výběru kandidáta) se tedy řadí $\mathrm{k}$ mechanismům ex ante, tyto mechanismy předcházejí samotnému aktu delegace, zatímco poslední dva mechanismy (monitoring a požadavek na self-reporting, institucionální omezení a kontrola) jsou mechanismy ex post, tj. následují až po aktu delegace (Lupia 2006: 45). Smlouvu v pŕípadě vztahu volič-zástupce nahrazují volební pravidla, určitou formou smlouvy mezi voličem a jeho zástupcem jsou i volební sliby. Kandidáti nabízejí svým voličům své služby, jejichž výstupy prezentují ve volební kampani. Voliči je svým výběrem akceptují jako smluvní podmínky vzájemného delegačního vztahu. Při výběru vhodného kandidáta tradičně napomáhaly voličům politické strany tím, že sdružovaly pod jednou ideologií jedince s podobnými názory (Strøm et al. 2006; Downs 1957). Zatímco empirická politologie považuje politické strany za taǩrka nezbytnou součást demokratické reprezentace, plnící významnou funkci agregace zájmů, pro teoretiky demokracie byla jejich existence okrajovou záležitostí mocensky sloužící politickým elitám, nikoli jako prostředek reprezentace (Urbinati a Warren 2008: 400). Jedním ze základních definičních znaků vztahu principála a agenta je existence informační asymetrie. Principál (volič) nemá možnost získat všechny informace ohledně kroků svého voleného zástupce. V př́padě parlamentního režimu je riziko informační asymetrie větší, nebot' celý řetězec delegace je méně transparentní než v prezidentském režimu díky množství nepřímých delegačních vztahů. Monitoring napomáhá snižování ztrát delegačního vztahu a mủže být prováděn externě. Důležitou roli sehrává v otázce monitoringu důvěra. Pokud principál nemá důvěru $\mathrm{v}$ instituce, které monitoring provádějí, př́ípadně není-li monitoring prováděn vůbec, jsou delegační vztahy narušeny. Pakliže principál nekontroluje nijak svého agenta, de facto na svou moc rezignuje (Lupia a McCubbins 2000).

\section{a. Nepravá informační asymetrie}

Poth a Selck (2009) zavádějí při aplikaci PA na politické rozhodovací procesy termín nepravé informační asymetrie (artificial information asymmetry). Principál má dostatek informací, přsesto je pro něj výhodnější tvářit se, že informace nemá 
a zvolit si agenta jako „obětního beránka“. Tradiční modely PA se zabývají jednodimenzionální problematikou delegace a berou zpravidla pozici principála jako znevýhodněnou z hlediska informační asymetrie. Poth a Selck zdůrazñují, že je otázka nepravé informační asymetrie v politologii velmi podceňována. V jejich konceptu se jedná o model dvojdimenzionálního vztahu principála a agenta, který zahrnuje agenta, principála a aktéra, který je zároveň principálem i agentem v jiné části řetězce.

Poth a Selck (2009: 141) vysvětlují svůj koncept nepravé informační asymetrie na zjednodušeném řetězci vztahů. Jsou-li osobně motivované cíle agenta odlišné od cílů jeho principála, ocitá se agent $\mathrm{v}$ situaci, kdy je pro něj výhodné porušit daná pravidla a zároveň se pokusit zvolit takovou strategii, jež mu umožní vyhnout se trestu, který mu za toto chování hrozí. Cílem agenta tedy je delegovat odpovědnost na dalšího agenta, nebot' existuje předpoklad, že agent nebude považován za odpovědného za činy, které nebyly pod jeho prrímou kontrolou. Znevýhodněný principál nedokáže podle logiky informační asymetrie správně odlišit agenta (principála $\mathrm{v}$ následujícím vztahu $\mathrm{v}$ řetězci), který nemohl kontrolovat výstupy a agenta, který je záměrně nechtěl kontrolovat.

Strategie nepravé informační asymetrie může být použita v situacích, kdy cíle principála a agenta $\mathrm{v}$ dalším článku řetězce jsou shodné, a zisky plynoucí $\mathrm{z}$ této situace převažují rizika uplatnění trestu v prvotním vztahu PA. Porušování pravidel a vystavování se sankcím se může zdát neracionálním, prostředí nepravé informační asymetrie a možnost přesunutí odpovědnosti na nevoleného agenta, objasňuje zdánlivě neracionální motivaci aktérů např́ílad $\mathrm{v}$ př́padě politické korupce (srv. Otáhal 2007).

V otázce monitoringu se můžeme setkat s implementací třetího aktéra do delegačního řetězce. Lupia a McCubbins (Lupia a McCubbins 1998; Lupia a McCubbins 2000; Lupia 2006) vytvořili model delegačního řetězce, jehož třetím aktérem je tzv. komunikátor. Reflektují význam sociální interakce v rozhodování voliče jako ultimátního principála. Komunikátor může pomoci principálovi minimalizovat ztráty delegačního procesu, základním předpokladem jejich úspěchu je ale důvěra. Pokud je důvěra principála v komunikátora nízká, jeho ochota jednat podle komunikátorových doporučení bude nízká, stejně jako efektivita delegace. Častěji se setkáme s třetím aktérem v pozici kontrolora, jehož role je spíše pasivní dozor (Gilardi a Braun 2002; Weingast a Moran 1983;

\footnotetext{
${ }^{9}$ Poth a Selck svou analýzu provádějí za pomoci herně teoretického př́stupu. $\mathrm{V}$ jejich terminologii se ve vztahu voliče a jeho zástupce jedná o hru s jednou vedlejší hrou (subgame). K problematice teorie her obecně a hlavní hry s několika vedlejšími hrami viz Říchová (2000: 105-115). Prostředí politického rozhodování je v moderních zastupitelských demokraciích natolik komplexní, že se vždy jedná o nějakou formu mnohoúrovňové herní sady. Jako víceúrovňovou herní sadu můžeme charakterizovat např. i Strømův řetězec delegace. Ačkoli herní terminologie může působit poněkud abstraktně, prakticky tento koncept nabízí možnost interpretovat mnohé situace z každodenního politického života.
} 
Weingast 1997). V otázce demokratické delegace je monitoring otázkou zejména existence právního státu (rule of law), jako garanta ochrany práv a zájmů občanůvoličů. Každý vztah PA v sobě nese potřebu monitoringu, můžeme však předpokládat, že ex post mechanismy jsou méně efektivní a pro principála je racionální posílit roli ex ante mechanismů při výběru principála. Selektivní model politické reprezentace definuje ve vztahu PA existenci „selektivního jádra“ a „okraje sankcí" (Mansbridge 2011: 622).

Vztah principála a agenta je charakteristický rovněž asymetrií priorit prioritou agenta je maximalizovat svůj zisk (např. udržet si mandát), což nemusí vždy korespondovat s cíli principála (minimalizace nákladů, maximalizace výstupů). Prostředí politiky nikdy neumožňuje vítězům voleb (agentům) nastavit si podmínky plnění kontraktu s voliči (principály) zcela podle svých představ a potřeb (Moe a Caldwell 1994: 173).

\section{b. Vlastní zájem}

Sledování vlastního zájmu je jedním ze základních axiomů teorie PA. Kritici tohoto př́stupu, Bosse a Phillips (2016), místo tradičního konceptu „narrowly self-interested“ přicházejí s konceptem omezeného sledování vlastního zájmu „bounded self-interested“. Hranice představují vnímané hodnoty a normy. Aktérí zkoumaného vztahu sledují vlastní zájem jen do té doby, není-li porušeno některé z jimi vnímaných pravidel. Hlavní normou omezující vlastní zájem aktérů je podle nich „férovost“", ta vyvolává v jejich chování pozitivní nebo negativní reciproční reakci. Samu férovost pak rozdělují na dva základní typy - distribuční a procedurální.

Distribuční férovost se týká materiálního zajištění - předpokládá se, že agent i principál chtějí ze vzájemného vztahu získat maximální materiální výstup, který lze v dané situaci považovat za férový. Stejným způsobem uvažují i o druhém aktérovi a jeho požadavcích a nárocích na materiální výstupy. Druhý typ férovosti - procedurální - se týká průběhu rozhodovacího procesu. Předpokladem je, že aktéŕi zpravidla považují průběh rozhodování za férový, pokud jsou brány v potaz jejich názory, rozhodování má standardizovaný a předvídatelný průběh, v procesu jsou využity odpovídající informace apod.

Vnesení rozměru spravedlnosti do vztahů principála a agenta přináší základ pro řešení mnoha problémů. Předpoklad omezeného sledování vlastního zájmu pak teorii přibližuje reálným vztahům a pomáhá snáze vysvětlit motivace aktérů jako kombinace spravedlivé distribuce materiálních výstupů a spravedlivého prístupu v rozhodovacím procesu (Bosse a Phillips 2016). Míra vnímání spravedlnosti na straně agenta vede ke stavu, který Bosse a Phillips (2016: 283-4). nazývají negativní vs. pozitivní reciprocita. $V$ př́padě pocitu nespravedlnosti sice klesají náklady na odměny a sledování agenta. Zároveň ale klesá jeho efektivita a v konečném součtu prináší proces delegace velmi omezený zisk. $V$ prípadě 
pozitivní reciprocity, tj. stavu, kdy agent má pocit, že je s ním zacházeno spravedlivě, dokonce nad jeho vlastní očekávání, jsou vstupní náklady na proces delegace vyšší než $\mathrm{v}$ prvním př́padě. Přesto výsledný zisk daný vysokou efektivitou agenta tyto náklady pokryje.

Koncept omezeného sledování vlastního zájmu může v př́padě vztahu volič - volený zástupce přesunout pohled směrem k principálovi (voliči). Podle tohoto konceptu bychom měli předpokládat, že čím větší má volený zástupce pocit nespravedlivého zacházení, tím větší bude jeho motivace jednat v rozporu s danými pravidly delegace. Takové jednání je obvykle v rozporu se zájmy voliče, volený zástupce, který nemá dostatečnou vidinu odměny, je ve svém jednání motivován zejména vlastní maximalizační funkcí (srv. Stokes 1999). Dalším dilematem je informovanost principála, který zpravidla nedisponuje takovými informacemi, aby byl schopen na základě zpětné indukce správně vyhodnotit agentovo jednání. Čím vážnější jsou informační nedostatky voliče jako ultimátního principála, tím více je ohrožena efektivita delegačního vztahu a kvalita odpovědnosti (Müller et al. 2006: 26).

\section{Tabulka 1: Specifika vztahu volič-zástupce}

\begin{tabular}{|l|l|}
\hline Principál & Agent \\
\hline Mnohonásobný principál & Kolektivní agent \\
\hline Heterogenita priorit a cílů & Není agentem pouze jednoho principála \\
\hline $\begin{array}{l}\text { Ne vždy provádí monitoring } \\
\text { Existence komunikátora jako prostředníka } \\
\text { vztahu PA }\end{array}$ & Strategie nepravé informační asymetrie \\
\hline $\begin{array}{l}\text { Principálův morální hazard (Madisonovo } \\
\text { dilema) }\end{array}$ & Sleduje vlastní zájem pouze omezeně \\
\hline
\end{tabular}

Zdroj: Autorka.

Delegační vztahy $\mathrm{v}$ situaci demokratické reprezentace mají oproti ekonomickým vztahům ve firmách významná specifika (Tabulka 1). Nejvýznamnější odlišností je komplexnost vztahů v politice, tj. existence mnohonásobného principála, ale i mnohonásobného agenta. Ač pro pochopení základních vztahů můžeme využít zjednodušení na mikroúroveň jednotlivců (viz Strøm 2000), nelze opomenout úskalí, které přináší transformace modelu na systémovou úroveň. Analýza politické reprezentace redukovaná na individuální úroveň vztahu volič - volený zástupce opomijí kontext, ve kterém se tento vztah odehrává a který jej determinuje (Pitkin 1967: 221). Katz (2014) vidí vážný problém při aplikaci PA na vztah voliči - politické strany ve faktické existenci dvou odlišných principálů. Politická strana ve vládě musí svá rozhodnutí přizpůsobovat požadavkům voličů, ale i zbytku členské základny. Podle něj zájmy těchto dvou principálů mohou být vzájemně velmi odlišné až neslučitelné. Tuto 
jeho námitku lze však vyřešit adaptací modelu s využitím jak konceptu mnohonásobného principála, tak omezeného vlastního zájmu. Ač požadavky voličů i členů strany mohou být odlišné, sdílí vybraný zástupce se základnou politické strany svůj primární cíl a tím je znovuzvolení.

\section{6. К̌Retězec delegace podle typu režimu}

$\mathrm{Na}$ podobu vztahu principála a agenta mají pochopitelně vliv demokratické instituce, v jejichž kontextu se rozhodování odehrává (nap̌r. typ režimu, volební systém, stranický systém, typ stran a postavení konkrétního politika v rámci strany). Zatímco v parlamentarismu (Obrázek 1a) jsou delegační vztahy charakterizovány řetězcem nepřímé delegace, v prezidentském režimu (Obrázek 1b) se jedná o mř́̌žku komplexních delegačních vztahů (Strøm 2000; Strøm 2006). Vliv agenta na výstupy je ale vobou modelech shodně rozprostřen mezi následující články delegačního řetězce. Model delegačního řetězce (chain of delegation) znázorňuje základní rozdíly ve fungování parlamentního a prezidentského režimu (Strøm 2006; Strøm 2000).

Přes notnou dávku zjednodušení, kterou s sebou tato míra abstrakce přináší, umožnily nástroje institucionálního prrístupu Strømovi schematické znázornění delegačního řetězce v parlamentarismu westminsterského typu vs. prezidencialismu typu USA. Na první pohled je z nákresu patrný rozdíl delegačních řetězců obou režimů. Oproti prezidencialismu je delegační řetězec v parlamentarismu výrazně jednodušší a prímočařejší, což jasně dokazuje jednoduchost delegačních vztahů v daném typu režimu. Voliči rozhodují o složení legislativní moci, premiér a vláda jsou agenty parlamentní většiny, jíž jsou také odpovědní (Samuels a Shugart 2010: 26). Na druhou stranu je však třeba poukázat na to, že delegační řetězec $\mathrm{v}$ parlamentarismu je dlouhým řetězcem nepřímé delegace, což zvyšuje riziko ztrát a narušuje vztahy odpovědnosti (Lupia 2006). Strømův model delegačního řetězce je silně zaměřen na rozlišení fungování obou typů režimů (navíc v jejich ideální podobě), analyzuje především další části řetězce, přičemž př́liš neproblematizuje jeho začátek. Začátek delegačního řetězce, tj. odevzdání moci z rukou lidu do rukou volených zástupců, v sobě ale skýtá několik významných odlišností oproti obdobnému vztahu ve firmě, pro které byla tato teorie vytvořena.

Shugart (2005) navíc doplňuje model delegačních vztahů $\mathrm{v}$ poloprezidentském ${ }^{10}$ režimu, přičemž se jedná o dva modely v závislosti na tom, zda jde o premiérsko-prezidentský nebo prezidentsko-parlamentní typ. Ty se vzájemně odlišují až v další úrovni delegace moci, výchozí pozice volič-zástupce je v obou př́padech stejná. Model PA podle něj poskytuje vedle tradičního

10 Ač kategorie poloprezidentského režimu je sama o sobě předmětem odborných diskuzí, z hlediska zkoumání delegačního řetězce považuji za smysluplné Shugartův model alespoň zmínit. 
hierarchického pojetí alternativní aparát pro zkoumání autority (Shugart 2005: 328).

\section{Obrázek 1: Schéma delegačního řetězce v parlamentním a prezidentském režimu}

a)

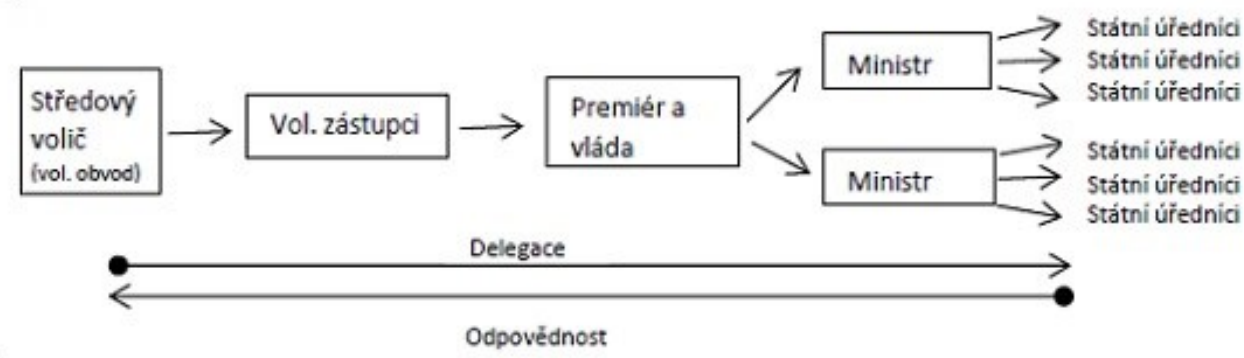

b)

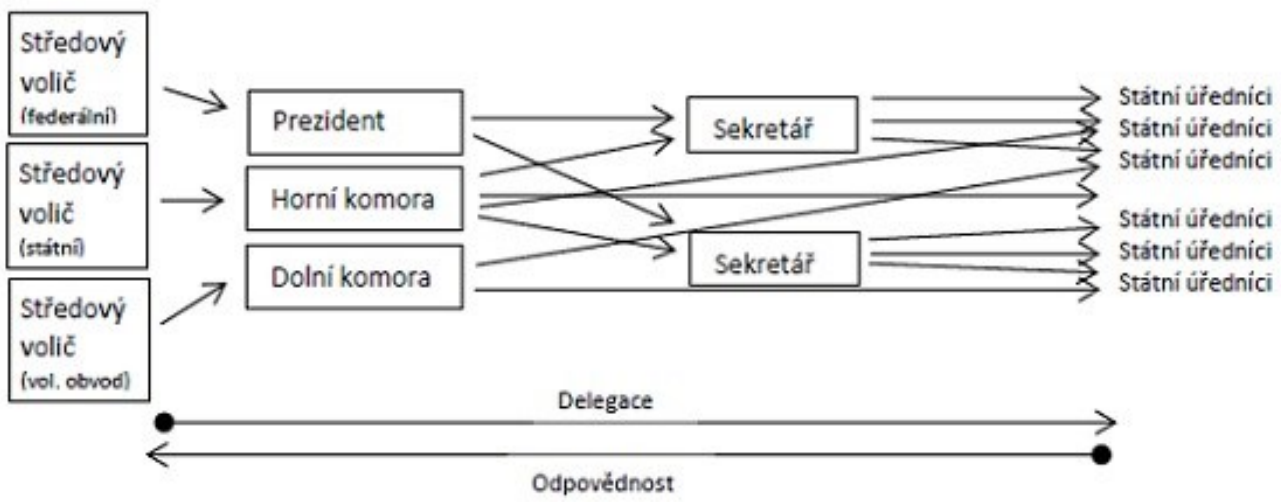

Zdroj: Přeloženo podle Strøm (2006: 65).

Všechny zmiňované modely delegačního řetězce pracují na samém počátku s premisou existence středového voliče, jehož zájmy jsou v řetězci reprezentovány. $\mathrm{V}$ reálném rozhodovacím procesu není agent nikdy agentem pouze jednoho principála. Vyvstává tak otázka mnohonásobného principála, jehož dilematem je i neexistence jednotného hodnotového systému, vysoká míra nepředvídatelnosti chování a nejednotnost cílů. Strøm sice upozorňuje, že řetězec delegace (v obou jím analyzovaných režimech) má ve skutečnosti tvar přesýpacích hodin (Strøm 2000: 270), kdy na začátku je velké množství voličů (principálů) a na jeho konci velké množství úředníků (agentů), kteří politiku realizují. Přesto jeho model pro větší názornost pracuje s předpokladem existence jednotného principála.

Vliv dělby moci na podobu dalších článků $\mathrm{v}$ delegačním řetězci podrobně rozebírají Samuels a Shugart (Samuels a Shugart 2010). Ačkoli se z řetězce delegace $v$ parlamentním režimu může zdát, že řetězec je přímý, oddělení 
legislativní a exekutivní moci, ke kterému v něm dochází, působí na fungování politických stran a to jejich vnitřním štěpením na stranu ve vládě a stranu v legislativě (Samuels a Shugart 2010: 46; Katz 2014). Priority obou segmentů $\mathrm{v}$ rámci strany se přitom mohou významně lišit. Strana jako celek pak stojí před další výzvou, které musí ve svém působení čelit. Situace může být ještě komplikovanější a výsledný řetězec delegačních vztahů mnohem komplexnější, jeli exekutiva částečně nebo zcela volena přímo.

\section{Vliv volebního a stranického systému na podobu vztahů PA}

Dopady volebního systému na kvalitu delegačních vztahů se zdají být při prvním pohledu žrejmé. Volič jako principál vždy disponuje vyjednávacím ultimátem v podobě možnosti daného zástupce (agenta) již opětovně nezvolit. Síla vyjednávacího ultimáta je ve vztahu volič-zástupce významně ovlivněna volebním systémem. Můžeme předpokládat, že čím více je posilněna personalizace volby, tím zřejmější je výkon ultimáta. Aktér disponující vyjednávacím ultimátem mưže překládat nabídku „ber nebo neber“ (take it or leave it), je formálně veto aktérem (veto player), nebot' jeho rozhodnutí umožňuje změnit status quo (Tsebelis 1995). Platí-li pravidlo, že čím větší je počet veto aktérů, tím těžší je změnit status quo (Tsebelis 1995: 317), bude použití principálova vyjednávacího ultimáta ve velkých volebních obvodech, příp. v systémech poměrného zastoupení, výrazně méně efektivní. Pozici voliče může $\mathrm{v}$ těchto př́padech posilit existence druhého principála (politické strany), která může v zájmu zachování voličské podpory sama přikročit k použití sankce vůči ,neposlušnému agentovi“.

Nicméně jak upozorňuje Mitchell (2000: 346) předpoklad, že volby v jednomandátovém volebním obvodu poskytují kvalitnější základ pro delegační vztahy volič-zástupce, je spíše mýtem. Omezená možnost volby v takovém volebním systému naopak představuje zvýšené riziko nepř́iznivého výběru. To lze výrazně snížit rovněž působením politických stran (Downs 1957; Müller et al. 2006; Müller 2000; Strøm 2006). V politických stranách dochází k prověření kandidátů předtím, než jsou nabídnuti voličům (principálům) $\mathrm{k}$ výběru ve volbách (Strøm 2000). Skutečný vliv agenta na výstupy politik je přitom omezen dalšími články delegačního řetězce bez ohledu na způsob jeho výběru.

Model PA vycházející z premis Downsova ekonomického modelu demokracie chápe politické strany jako „sdružení jednotlivých politikư،. Katz upozorňuje, že tento model může být s omezenou platností vhodný pouze v prostředí USA, evropské politické strany se chovají jinak. V downsovském pojetí politiky jsou politické strany reprezentanty heterogenní masy voličů, politika tak vykazuje znaky dostředivosti. Tradiční evropské politické strany však reprezentovaly spíše určitý segment společnosti, který oslovovaly skrze svůj program (Katz 2014: 184). Je nepochybné, že aplikace modelu na systém USA a na některou z tradičních evropských demokracií přinese požadavek na rozdílnou 
adaptaci, nicméně výstupy nemusí být nutně mylné. Význam tradičních politických stran při prověření kandidátů hraje zejména $\mathrm{v}$ evropských podmínkách v celém řetězci delegace nezastupitelnou roli (Strøm 2000; Lupia 2006; Müller 2000). Oslabování role politických stran a posun od ideologií k volebním kampaním vedeným marketingovými firmami může mít vliv na kvalitu výběru agenta a následně způsobit vyšší ztrátu v delegačním vztahu. Roli politických stran v delegačním procesu nazývají Dalton et al. (Dalton et al. 2011: 7) řetězcem demokratických vazeb (chain of democratic linkage). Tento řetězec má pět článků - kampaň, participace, ideologie, reprezentace a implementace politik. Cím silnější jsou vazby mezi jednotlivými články řetězce, tím lépe podle nich plní vláda svou reprezentativní funkci.

\section{Adaptace modelu PA v podmínkách ČR}

Základní schéma delegačního řetězce je velmi zjednodušující a při pohledu na něj vyvstává hned několik závažných námitek. Problematický není pouze začátek řetězce a jeho znázornění prostým zobecněním na stř̌edového voliče, jemuž jsem se věnovala výše. Chápeme-li další článek řetězce jako vytvoření exekutivy na základě parlamentní (legislativnî) většiny (Samuels a Shugart 2010: 26), je nutné položit si otázku, jak lze z pohledu tohoto schématu řešit problematiku např̀. menšinových vlád, nebo namítnout, že dané schéma nijak nereflektuje reprezentaci zájmů opozice. Český ústavní systém se až do roku 2012, kdy byla ústavním zákonem zavedena prímá volba prezidenta, velmi blízil tradičnímu schématu parlamentarismu. Zavedením přímé volby prezidenta by se mohlo zdát, že se ČR stala poloprezidentským režimem, nicméně tomu tak rozhodně není (Brunclík a Kubát 2017). Ačkoli přímo volený prezident nemá jiné kompetence, než měli jeho nepřímo volení předchůdci, praxe výkonu mandátu prvním př́movoleným prezidentem ukazuje, že je nezbytné přímou volbu v delegačním řetězci reflektovat. Silný prezidentský mandát narušuje vztahy v doposud př́mém parlamentaristickém delegačním řetězci.

Z Obrázku 2 je patrné, že delegační vztahy jsou v podmínkách českého parlamentarismu poněkud složitější, než je tomu v př́ípadě westminsterského modelu. V legislativním procesu je nutné zahrnout vliv Senátu na výsledné výstupy, který je realizován skrze legislativní proces a dolní komoru, nicméně jeho možnosti uplatnit monitoring či sankce je de facto nulový. Podobně specifickou pozici zaujímá i prezident, který má díky prímé volbě silný mandát od voličů, nicméně jeho vliv na dalši články delegačního řetězce je nepatrný. Jak jsem uvedla výše, vzhledem $\mathrm{k}$ dosavadní praxi prvního prímo voleného prezidenta považuji za nezbytné jej v delegačním řetězci zahrnout, nebot' už pouhý vliv na výběr osoby premiéra (jakkoli může být považován za formálnî) se ukazuje být významným determinantem dalšího směřování politiky. Na druhou stranu tento vztah je ryze jednostranný a podobně jako u Senátu se de facto nejedná o vztah principála 
a agenta, nebot' chybí vztah odpovědnosti agenta principálovi. Voliči tedy předávají ve volbách moc, jejíž výkon je značně omezený. Vyvstává otázka, zda si tento fakt při výběru zástupců uvědomují. Nízká úroveň zájmu o volby do Senátu ${ }^{11}$ mezi českými občany by spíše naznačovala, že očekávání voličů od výkonu takto silného mandátu nejsou naplněna a jejich přirozenou reakcí je ztráta zájmu o tento delegační vztah. Na problematiku silného mandátu a omezených kompetencí upozorňovala odborná veřejnost při debatách o zavedení přímé volby prezidenta.

\section{Obrázek 2: Delegační schéma v podmínkách českého parlamentního režimu}

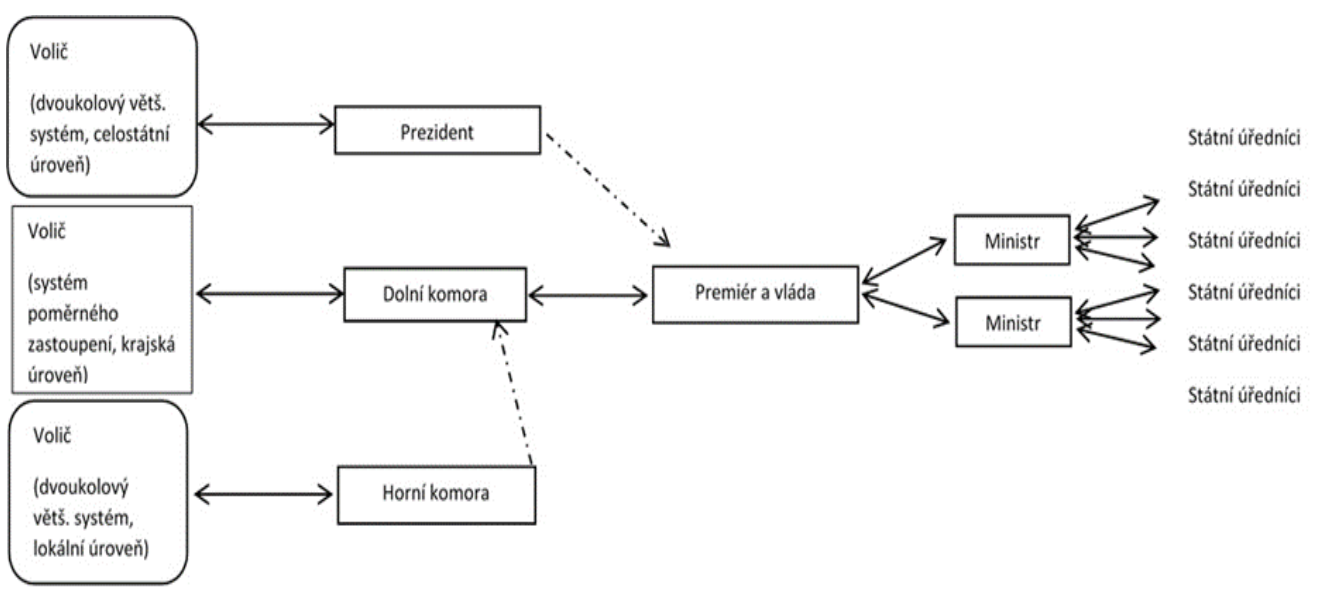

Poznámka: Oboustranné šipky znázorňují vztahy delegace a odpovědnosti, přerušované šipky pouze vztahy delegace - tj. vliv daného principála na výstup (př́p. výběr agenta), bez možnosti jeho kontroly.

Zdroj: Autorka.

Podobně toto schéma jasně ukazuje na problematičnost prezidentských zásahů do výkonu exekutivy. Vláda v parlamentarismu odvozuje svou legitimitu pŕímo z dolní komory parlamentu, nezávisle na vưli prezidenta (srv. Dvořák 2017: 16), proto snaha prezidenta dosadit „svého“ premiéra, bez podpory Poslanecké sněmovny, znamená de facto popření základního principu zastupitelské demokracie. Podobně deficitní je z tohoto pohledu i vládnutí vlády bez důvěry sněmovny, ačkoli její představitelé a premiér pocházejí z vítězné strany parlamentních voleb.

Při hodnocení současného fungování českého parlamentarismu prizmatem teorie principála a agenta narazíme vedle problematického postavení prezidenta

11 Volební účast činila ve volbách v roce 2016 v prvním kole 33,5\% a ve druhém kole pouze 15,4\%. [https://www.volby.cz/pls/senat/se31 ?xjazyk=CZ\&xdatum=20161007\&xv=0] 
a horní komory ${ }^{12}$ pochopitelně i na další témata, která neplynou z analýzy schématického znázornění. Český parlamentarismus je dlouhodobě kritizován pro svou nízkou míru efektivity (např. Kubát 2013). Je-li centrálním vztahem otázka demokratické reprezentace zájmů, měla by je odrážet svou strukturou i dolní komora parlamentu. Podle Downse (1957: 202) je pro efektivitu vlády důležitým determinantem míra nejistoty v delegačním procesu. Čím vyšší je nejistota, tím méně efektivní je vláda, nebot' se v důsledku sledování vlastního zájmu, jímž je znovuzvolení, zdráhá činit závažná rozhodnutí. Vysoká voličská volatilita tedy zvyšuje pravděpodobnost delegačních ztrát. $\mathrm{Na}$ druhou stranu, pokud je výsledek voleb heterogennější než je distribuce zájmů ve společnosti, vede to v konečném důsledku opět $\mathrm{k}$ nestabilitě a neefektivitě.

\section{Závěr}

V literatuře zabývající se výzvami současné demokracie, at' už v nově se demokratizujících zemích nebo v tradičních demokraciích, se stále častěji setkáme s kritikou chápání demokracie jako nedosažitelného ideálu (např. Achen a Bartels 2016; Dufek 2014; Urbinati a Warren 2008). Empirické př́stupy bývají naopak kritizovány pro absenci snah o reflexi normativních teorií. Achen a Bartels (2016) proto přicházejí s konceptem „demokracie pro realisty“, který pracuje s demokracií jako živou každodenní skupinovou realitou občanů. Demokracie je zároveň prostředek i cíl (Urbinati 2014: 10). Občané jsou konečným arbitrem otázky reprezentace a odpovědnosti $\mathrm{v}$ demokracii. Z jejich pohledu a $\mathrm{z}$ hlediska konstituce legitimity režimu na individuální úrovni se debaty o podstatě reprezentace zdají být poněkud nadbytečné, v centru zájmu jsou př́edevším výstupy politik (Arnesen a Peters 2017). Z těchto premis vychází i úvaha přenést těžiště studia kvality demokracie na první článek delegačního řetězce a vytvořit rozšířený model PA pro popis tohoto vztahu. Dosud vytvořené modely se zaměřují především na chování volených zástupců jako agentů v tomto vztahu. Demokracie třetí vlny však mají jedno významné specifikum a tím je „demokratizace pozpátku“ (Rose a Shin 2001). Svobodné volby, jakožto jeden $\mathrm{z}$ hlavních atributů demokracie, stály $\mathrm{v}$ těchto zemích (na rozdíl od demokracií předchozích vln) na počátku demokratizačního procesu. Další atributy demokracie a demokratické reprezentace se utvářely až posléze. Z pohledu modelu PA došlo tedy nejprve k předání pravomocí, vytvoření delegačního vztahu mezi principálem a agentem, pravidla hry však byla velmi nejasná. Úskalím tohoto procesu je také principálova kompetentnost, prríp. kvalita principála - občana (Roberts 2016).

12 Autorka tímto rozhodně nepopírá smysluplnost existence Senátu jako takového, spíše jen poukazuje na nevýhodnost jeho pozice z pohledu delegace moci a síly prrímého mandátu. 
Kvalita vztahů v delegačním řetězci bezpochyby ovlivňuje kvalitu demokracie jako takové (Powell 2004). Zatímco Roberts (2010: 38) spojuje měření kvality demokracie vedle dalších indikátorů i s mírou plnění slibů, Downs (1957: 107) upozorňuje, že $\mathrm{v}$ př́ípadě vládnoucí politické strany může být programová odpovědnost (reliability) nahrazena voličskou odpovědností (responsibility). ${ }^{13}$ Důraz na responzivitu, tj. míru plnění slibů a politiku reagující na aktuální požadavky občanů, je podle Sabla (2015: 346) typický pro empiricky orientované autory. Teoretici demokracie naopak responzitivu mezi hlavní indikátory kvality demokracie neřadí. Jedním z možných paradoxů responzivity je podle něj podpora veřejnosti ústavnímu systému, který v sobě obsahuje pojistky bránící absolutní responzivitě (Sabl 2015: 353). Tato situace je praktickým př́kladem Madisonova dilematu. Dokonale responzivní politika by ve svém důsledku mohla znamenat i ohrožení demokracie.

Výzkum kvality demokracie zaměřený primárně na kvalitu výstupů vztahů $\mathrm{v}$ delegačním řetězci reaguje na př́lišné zjednodušení používaných indexů demokracie (např. Freedom House, Polity či Vanhanenův Index). Aplikace ekonomických schémat na politiku s sebou sice rovněž přináší notnou míru zjednodušení, domnívám se však, že i přes tyto objektivní překážky, může jít o inspirativní interpretační rámec pro pochopení delegačních vztahů jako základů moderní demokracie. Popis delegačního vztahu mezi voliči a jejich volenými zástupci terminologií PA adaptovanou na prostředí politiky umožňuje schematizovat tento esenciální demokratický vztah a komplexně zahrnout do studia kvality demokracie poznatky několika souvisejících politologických teorií a konceptů (např. prospektivní a retrospektivní volba, odpovědnost atd.). Besley (2006: 111) mluví o modelu PA jako o „vhodném způsobu uvažování o determinantech kvality vlády“ (srov. Morlino 2012; Rothstein a Teorell 2008).

Demokracii zcela jistě nelze omezit na otázku volební reprezentace (Pitkin 1967), můžeme však předpokládat, že kvalita volební reprezentace (tj. vztahu PA mezi voličem a jeho zástupcem) do značné míry determinuje jak kvalitu dalších forem reprezentace, tak kvalitu vztahů v následujících článcích řetězce delegace. Společenské vztahy jsou vždy dynamické a jednoduchý statický model je nemůže nikdy zcela obsáhnout. Pohled na vztah voliče a jeho zástupce prizmatem teorie principála a agenta může při své schematičnosti jasněji ukázat některá rizika, se kterými se oba aktéŕi vztahu potýkají. Jak velmi je tento vztah ovlivněn kontextem? Jaké škody způsobuje informační asymetrie? Jaké mechanismy naopak vedou ke snížení těchto ztrát? Jak moc je kvalita vztahů ovlivněna rozdílným chápáním delegačního vztahu, prríp. jaké škody způsobuje v tomto vztahu principálova nepředvídatelnost? Nejen tyto zásadní otázky zůstávají v současné literatuře zabývající se demokratickým procesem delegace, resp. řetězcem

13 Ačkoli Downs používá termín responsibility, v dnešním politologickém pojmosloví se spíše jedná o odpovědnost ve smyslu accountability, prŕp. Morlinovo responsiveness (Morlino 2004). 
delegace, nezodpovězeny. Podrobný rozbor delegačního vztahu voliče a jeho zástupce by prritom mohl napomoci popisu a lepšímu pochopení současných změn $\mathrm{v}$ těchto vztazích, resp. pochopení změn ve voličském chování a adaptace politických stran na tyto změny.

\section{Literatura}

Achen, Christopher H. a Larry M. Bartels (2016): Democracy for realists: why elections do not produce responsive government. Princeton: Princeton University Press.

Alvarez, R. Michael a Thad E. Hall (2006): „Controlling democracy: The principal-agent problems in election administration." Policy Studies Journal 34(4), 491-510. DOI: $10.1111 / j .1541-0072.2006 .00188 . x$

Arnesen, Sveinung a Yvette Peters (2017): „The Legitimacy of Representation: How Descriptive, Formal, and Responsiveness Representation Affect the Acceptability of Political Decisions.“ Comparative Political Studies. DOI: 10.1177/0010414017720702

Bahenský, Vojtěch (2014): Podpora povstaleckých hnuti jako nástroj zahranični politiky státu. Bakalářská práce, Katedra politologie, Fakulta sociálních věd, Univerzita Karlova, Praha. Besley, Timothy (2006): Principled Agents? The Political Economy of Good Government. New York: Oxford University Press.

Besley, Timothy a Valentino Larcinese (2011): „Working or shirking? Expenses and attendance in the UK Parliament." Public Choice 146(3), 291-317. DOI: 10.1007/s11127009-9591-z

Bobek, Michal (2014): „Vliv vztahů zastoupení na kvalitu informací poskytovaných ověřovacími službami.“ Ceský finanǒni a účetni časopis 9(2), 52-68. DOI: $10.18267 /$ j.cfuc. 394

Bosse, Douglas A. a Robert A. Phillips (2016): „Agency Theory and Bounded SelfInterest. “ Academy of Management Review 41(2), 276-297. DOI: 10.5465/amr.2013.0420

Bottom, William P. (ed.) (2006): „Building a Pathway to Cooperation: Negotiation and Social Exchange between Principal and Agent." Administrative Science Quarterly 51, 29-58. DOI: $10.2189 /$ asqu.51.1.29

Bovens, Mark (2010): „Two Concepts of Accountability: Accountability as a Virtue and as a Mechanism." West European Politics 33(5), 946-967. DOI: 10.1080/01402382.2010.486119

Braun, Dietmar a David H. Guston (2003): „Principle-agent theory and research policy: an introduction." Science and Public Policy 30(5), 302-308. DOI: 10.3152/147154303781780290

Brim, Luboš a Pavel Dufek (2012): „Politická reprezentace individuální a kolektivní: K otázce teoretických základů demokracie na transnacionální úrovni." Politologický casopis XIX(2), 128-155.

Brunclík, Miloš a Michal Kubát (2017): Kdo vládne Česku? Brno: Barrister \& Principal.

Conconi, Paola a Nicolas Sahuguet a Maurizio Zanardi (2014): „Democratic Peace and Electoral Accountability." Journal of the European Economic Association 12(4), 997-1028. DOI: $10.1111 /$ jeea.12074

Dahl, Robert A. (2001): O demokracii: privodce pro občany. 1st ed., Praha: Portál. 
Dalton, Russell J. a David M. Farrell a Ian McAllister (2011): Political Parties and Democratic Linkage. Oxford: Oxford University Press.

Downs, Anthony (1957): An Economic Theory of Democracy. New York: HarperCollins Publishers.

Dufek, Pavel (2014): „K nespojitosti normativních a empirických teorií demokracie.“ In: Demokracie jako hodnota a problém II. Liberec: Technická univerzita v Liberci, 84-94.

Dufek, Pavel a Jan Holzer (2013): „Democratization of Democracy? On the Discontinuity between Empirical and Normative Theories of Democracy." Representation 49(2), 117-134. DOI? 10.1080/00344893.2013.816189

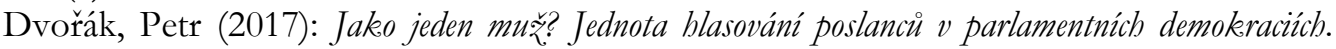
Brno: Centrum pro studium demokracie a kultury, Masarykova Univerzita.

Eisenhardt, Kathleen M. (1989): „Agency Theory: An Assessment and Review.“ The Academy of Management Review, 14(1), 57-74.

Fearon, James D. (1999): „Electoral Accountability and the Control of Politicians: Selecting Good Types versus Sactioning Poor Performance." In: Bernard Manin, Adam Przeworski a Susan C. Stokes (eds). Democracy, Accountability, and Representation. Cambridge: Cambridge University Press, 55-97.

Ferejohn, John (1999): „Accountability and Authority: Toward a Theory of Political Accountability." In: Bernard Manin, Adam Przeworski a Susan C. Stokes (eds). Democracy, Accountability, and Representation. Cambridge: Cambridge University Press, 131-153.

Gelnarová, Jitka (2010): „Reprezentace žen v politice z pohledu politické teorie aneb “Co všechno znamená, když se řekne, že ženy jsou v politice podreprezentovány?”“ Acta Politologica 2(2), 120-135.

Geys, Benny a Karsten Mause (2016): „The Limits of Electoral Control: Evidence from Last-Term Politicians." Legislative Studies Quarterly 41(4), 873-898. DOI: 10.1111/lsq.12136

Gilardi, Fabrizio a Dietmar Braun (2002): „Delegation aus der Sicht der Prinzipal-AgentTheorie." Politische Vierteljabresschrift, 43(1), 147-161.

Hlaváček, Jiři a Michal Hlaváček (2008): "Morálni hazard" a "neprǐznivý výbér" prí maximalizaci pravděpodobnosti ekonomického prězití. Working Papers IES 2006/22, Charles University Prague, Faculty of Social Sciences, Institute of Economic Studies, online (https://ideas.repec.org/p/fau/wpaper/wp2006_22.html).

Karlas, Jan (2011): „Národní parlamenty a kontrola záležitostí EU : typologická perspektiva.“ Stredoevropské politické studie XIII(4), 300-324.

Katz, Richard S. (2014): „No man can serve two masters: Party politicians, party members, citizens and principal-agent models of democracy." Party Politics 20(2), 183193. DOI: $10.1177 / 1354068813519967$

Kiewiet, D. Roderick a Mathew D. McCubbins (1991): The logic of delegation: Congressional parties and the appropriations process. Chicago: The University of Chicago Press.

Kubát, Michal (2013): Současná čská politika: co s neefektivním režzimem? Brno: Barrister \& Principal.

Lane, Jan-Erik (2009): „Political Representation From the Principal-Agent Perspective.“ Representation 45(4), 369-378. DOI: 10.1080/00344890903235421

Lupia, Arthur (2006): „Delegation and its Perils.“ In K. Strøm, W. C. Müller, a T. Bergman, eds. Delegation and Accountability in Parliamentary Democracies. Oxford: Oxford University Press, 33-54. 
Lupia, Arthur a Mathew D. McCubbins (2000): „Representation or abdication? How citizens use institutions to help delegation succeed." European Journal of Political Research 37(3), 291-307. DOI: 10.1111/1475-6765.00514

Lupia, Arthur a Mathew D. McCubbins (1998): The democratic dilemma: can citizens learn what they need to know?, Cambridge: Cambridge University Press.

Manin, Bernard a Adam Przeworski a Susan C. Stokes (1999): „Elections and representation." In: Bernard Manin, Adam Przeworski a Susan C. Stokes (eds). Democracy, Accountability, and Representation. Cambridge: Cambridge University Press, 29-54.

Mansbridge, Jane (2011): „Clarifying the Concept of Representation.“ American Political Science Review 105(3), 621-631. DOI: 10.1017/S0003055411000189

Mansbridge, Jane (2003): „Rethinking Representation.“ The American Political Science Review 97(4), 515-528. DOI: 10.1017/S0003055403000856

Marek, Petr (2007): „Vliv teorie zastoupení na teorii podnikových financí.“ Ceské finanční a účetní ćasopis 2(2), 6-16. DOI: 10.18267/j.cfuc.217

McCarty, Nolan a Adam Meirowitz (2007): Political Game Theory: an introduction. New York: Cambridge University Press.

Miller, Gary J. (2005): „The Political Evolution of Principal-Agent Models.“ Annual Review of Political Science 8(1), 203-225. DOI: 10.1146/annurev.polisci.8.082103.104840

Mitchell, Paul (2000): „Voters and their representatives: electoral institutions and delegation in parliamentary democracies." European Journal of Political Research 37, 335351. DOI: $10.1111 / 1475-6765.00516$

Moe, Terry M. a Michael Caldwell (1994): „The Institutional Foundations of Democratic Government: A Comparison of Presidential and Parliamentary Systems." Journal of Institutional and Theoretical Economics 150(1), 171-195.

Morlino, Leonardo (2004): "“Good” and "bad” democracies: how to conduct research into the quality of democracy." Journal of Communist Studies and Transition Politics 20(1), 527. DOI: $10.1080 / 13523270410001687082$

Morlino, Leonardo (2012): Changes for Democracy. Actors, Structures, Processes. Oxford: Oxford University Press.

Müller, Wolfgang C. (2000): „Political Parties in Parliamentary Democracies: Making Delegation and Accountability Work." European Journal of Political Research 37(3), 309333. DOI: $10.1111 / 1475-6765.00515$

Müller, Wolfgang C., T. Bergman, a Kaare Strøm (2006): „Parliamentary Democracy: Promise and Problems." In: Kaare Strøm, Wolfgang C. Müller a Torbjörn Bergman (eds). Delegation and Accountability in Parliamentary Democracies. Oxford: Oxford University Press, 3-32.

Otáhal, Tomáš (2009): „Problém zastoupení v nové institucionální ekonomii.“ Politická ekonomie 57(5), 677-695. DOI: 10.18267/j.polek.704

Otáhal, Tomáš (2007): „WHY IS CORRUPTION A PROBLEM OF THE STATE ?““ Prague Economic Papers 16(2), 165-179. DOI: 10.18267/j.pep.304

Pitkin, Hanna F. (2004): „Representation and democracy: Uneasy alliance.“ Scandinavian Political Studies 27(3), 335-342. DOI: 10.1111/j.1467-9477.2004.00109.x

Pitkin, Hanna F. (1967): The Concept of Representation. Berkeley: University of California Press.

Poth, Stephan a Torsten J. Selck (2009): „Principal Agent Theory and Artificial Information Asymmetry." Politics, 29(2), 137-144. DOI: 10.1111/j.14679256.2009.01349.x 
Powell, G. Bingham (2004): „The Chain of Responsiveness.“ Journal of Democracy 15(4), 91-105. DOI: $10.1353 /$ jod.2004.0070

Rehfeld, Andrew (2009): „Representation Rethought: On Trustees, Delegates, and Gyroscopes in the Study of Political Representation and Democracy." The American Political Science Review 103(2), 214-230. DOI: 10.1017/S0003055409090261

Rehfeld, Andrew (2011): „The Concepts of Representation.“ American Political Science Review 105(3), 631-642. DOI: 10.1017/S0003055411000190

Roberts, Andrew (2010): The Quality of Democracy in Eastern Europe: Public Preferences and Policy Reforms. New York: Cambridge University Press.

Roberts, Andrew (2016): „What Do We Know and What Do We Need to Know about Mass-Elite Linkages in the Czech Republic ?" Acta Politologica 8(2), 31-50.

Rose, Richard a Doh Chull Shin (2001): „Democratization Backwards: The Problem of Third-Wave Democracies.“ British Journal of Political Science 31(2), 331-354.

Ross, Stephen A. (1973): „The Economic Theory of Agency : The Principal's Problem.“ The American Economic Review 63(2), 134-139.

Rothstein, Bo a Jan Teorell (2008): „What is quality of government? A theory of impartial government institutions.“ Governance 21(2), 165-190. DOI: 10.1111/j.14680491.2008.00391.x

Říchová, Blanka (2000): Prebled modernich politologickeých teorií. Praha: Portál.

Ř́chová, Blanka, ed. (2015): Analýza politiky a politictí aktérí. Praha: Sociologické nakladatelství (SLON).

Sabl, Andrew (2015): „The Two Cultures of Democratic Theory: Responsiveness, Democratic Quality, and the Empirical-Normative Divide." Perspectives on Politics 13(2), 345-365. DOI: $10.1017 /$ S1537592715000079

Samuels, David J. a Matthew S. Shugart (2010): Presidents, Parties, and Prime Ministers: how the separation of powers affects party organization and behavior. Cambridge: Cambridge University Press.

Shugart, Matthew S. (2005): „Semi-Presidential Systems: Dual Executive And Mixed Authority Patterns.“ French Politics 3(3), 323-351. DOI: 10.1057/palgrave.fp.8200087

Schumpeter, Joseph A. (2004): Kapitalismus, socialismus a demokracie. Brno: Centrum pro studium demokracie a kultury.

Stokes, Susan C. (1999): „What Do Policy Switches Tell Us about Democracy?“ In: Bernard Manin, Adam Przeworski, a Susan C. Stokes, eds. Democracy, Accountability, and Representation. Cambridge: Cambridge University Press, 98-130.

Strøm, Kaare (2000): „Delegation and accountability in parliamentary democracies.“ European Journal of Political Research 37, 261-289. DOI: 10.1111/1475-6765.00513

Strøm, Kaare (ed.) (2006): „Dimensions of Citizen Control.“ In: Kaare Strøm, Wolfgang C. Müller, a Torbjörn Bergman (eds). Delegation and Accountability in Parliamentary Democracies. Oxford: Oxford University Press, 651-706.

Strøm, Kaare (2006): „Parliamentary Democracy and Delegation.“ In: Kaare Strøm, Wolfgang C. Müller, a Torbjörn Bergman (eds). Delegation and Accountability in Parliamentary Democracies. Oxford: Oxford University Press, 55-106.

Tsebelis, George (1995): „Decision Making in Political Systems: Veto Players in Presidentialism, Parliamentarism, Multicameralism and Multipartyism." British Journal of Political Science 25(3), 289-325. DOI: 10.1017/S0007123400007225 
Urbinati, Nadia (2014): Democracy disfigured: Opinion, Truth, and the People. Cambridge, Massachusetts: Harvard University Press.

Urbinati, Nadia a Mark E. Warren (2008): „The Concept of Representation in Contemporary Democratic Theory." Annual Review of Political Science 11(1), 387-412. DOI: 10.1146/annurev.polisci.11.053006.190533

Weingast, B.R. (1997): „The Political Foundations of Democracy and the Rule of Law.“ The American Political Science Review 91(2), 245-263. DOI: 10.2307/2952354

Weingast, Barry R. a Mark J. Moran (1983): „Bureaucratic Discretion or Congressional Control? Regulatory Policymaking by the Federal Trade Commission." Journal of Political Economy 91(5), 765-800. DOI: 10.1086/261181

Zajícová, V. (2015): Vnitruni organizace víceúrovñových politickéch stran. Prípad Itálie. Diplomová práce, Katedra evropských studií, Fakulta sociálních věd, Univerzita Karlova, Praha.

\section{Principal-Agent Theory and Its Use in Describing the Voter- Representative Relationship}

\section{SUMMARY}

Principal-Agent Theory (PA) originated as an economic theory analyzing the relations of delegation in companies, later finding its application in other areas of economics, such as in management and insurance, etc. Delegation relations are not only issues of economic theory, but of political science as well. The following article is above all a review article which aims to bring the Czech audience closer to this influential and interesting theory, as its use is rather marginal in Czech political science. Due to the multidisciplinary nature of the approaches, the paper first deals with the clarification of terminology, then presents the theoretical concept of the model of the principal and the agent coming from economics, an overview of several significant examples of its use in the question of democratic representation, and subsequently the design of the model of the voterrepresentative relationship in the context of the organization of democratic institutions in the Czech Republic. Its purpose is, in particular, to open up a scholarly discussion on the possible use of the model in examining the quality of Czech democracy.

The PA model works with two types of actors - the principal, i.e. the player who has the power, and the agent, i.e. the person to whom the power is delegated. Situations in which an analysis can be made using the Principal and Agent Theory model are characterized by structured relationships between the Principal and the Agent in which we can observe mutual cooperation, but with different goals and attitudes to risk. The basic issue in the relationship between the principal and the agent is the issue of controlling outputs. The principal's options to directly influence the decision-making of the agent are limited; the agent's actions are judged on the basis of the outputs and the degree of fulfillment of the main ideas of the best possible solution. The main characteristic of the relationship between the principal and the agent is therefore information asymmetry. The aim of the principal is to get the best result for the lowest 
possible cost. Direct agent review is impossible, or highly expensive. The quality of the relationship between the principal and the agent is therefore strongly supported by the consistency of preferences, while significantly different preferences of the two actors distort the relationship.

Decision-making and the delegation of powers in politics takes place in a much wider social context than firm decision-making. If PA applications are to bring meaningful results, it necessarily requires adaptation. Delegation occurs in a situation where it is no longer possible (whether in terms of capacity or competence) to make a direct decision. There is no uniform, universally applicable diagram for the analysis of representation. Each power delegation process reflects the different characteristics of the given actors, i.e. a particular principal and agent, and brings with it various pitfalls and losses caused by delegation. On the other hand, the model of mass democracy itself necessarily involves the need for the delegation of power if it is to maintain a certain degree of efficiency.

We can find relations of representation in other than democratic regimes; however, without the possibility of giving feedback in the form of accountability, representation is only apparent in such cases. Accountability and delegation are interrelated concepts: Delegation without accountability means only fake democracy. If we cannot reprimand our representatives in any way, if only, at the very least, to communicate our disagreement with their actions, representation becomes a mere fiction. The constitution of a relationship of accountability between voter and politician is the essence of democratic politics, so accountability lies at the heart of PA political models. The problem, of course, arises with regard to its enforceability.

Of course, the relationship between the principal and the agent is influenced by the democratic institutions in the context of which decision-making takes place (e.g. type of regime, electoral system, party system, type of party, and the importance of a particular party policy). While under parliamentarism, delegation relations are characterized by the chain of indirect delegation, the presidential regime is a grid of complex delegation relations. However, the influence of the agent on the outputs is equally distributed among the successive components in the delegation chain in both models. The type of electoral system also affects the form of relations in the delegation chain. However, as Mitchell points out, the presumption that elections in a single-member district provide a better basis for delegation-voter-deputy relations is more a myth. The limited choice in such an electoral system presents, on the contrary, an increased risk of making an unfavorable choice (adverse selection). This can also be significantly reduced by the influence of political parties. Political parties screen candidates before they are offered to voters (principals). The actual influence of the agent on policy outputs is limited by other components of the delegation chain, regardless of the selection model.

The basic scheme of the delegation chain is very simplistic and there are several serious objections to it. If we understand a subsequent component of the chain as creating an executive based on a parliamentary (legislative) majority, it is necessary to ask how the issue of, for example, minority governments can be addressed from the point of view of this scheme or to argue that the scheme does not reflect the representation of the interests of the opposition. The Czech constitutional system, until 2012, when the direct election of the President was introduced by the Constitutional Act, was very close to the traditional scheme of parliamentarism. By introducing the direct election of the president, 
it may seem that the Czech Republic has become a semi-presidential regime, but it is certainly not so. Although a directly elected president has no powers other than those of his indirectly elected predecessors, the practice of mandate by the first directly-elected president shows that it is necessary to reflect the direct election in the delegation chain. The strong presidential mandate disturbs relations in the hitherto direct parliamentary delegation chain.

The quality of relations in the delegation chain undoubtedly affects the quality of democracy as such. Democracy quality research, primarily focused on the quality of relations outputs in the delegation chain, responds to the over-simplification of the commonly-used democracy indices (e.g. Freedom House, Polity or Vanhanen Index) or to research focusing on responsiveness. While the application of economic schemes to policy also brings a considerable degree of simplification, I believe that, despite these objective obstacles, it may be an inspiring interpretative framework in which to understand delegation relations as the foundations of modern democracy. 